
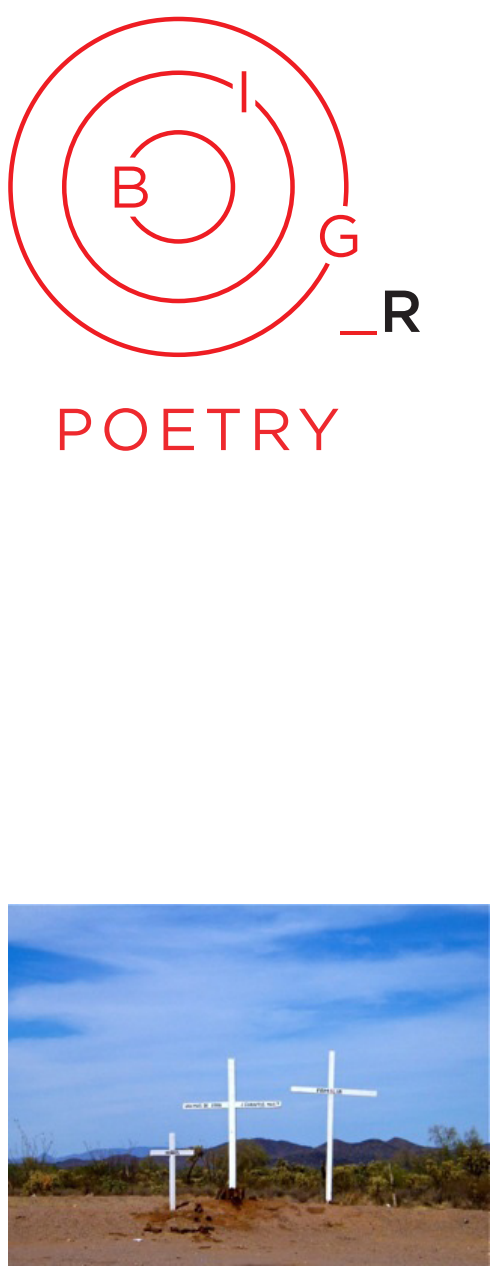

Photo credit: Roxanne Lynn Doty
Borders in Globalization Review

Volume 1, Issue 1 (Fall 2019): 113-114

https://doi.org/10.18357/bigr11201919272

\section{Hours of the Desert}

\author{
Roxanne Lynne Doty
}

\section{Poem:}

"Hours of the Desert"

(Version 2, July 16, 2018)

\section{About the Poet:}

Roxanne Lynne Doty teaches at Arizona State University and has written extensively on border issues. Publications include; "Bare Life: Border-Crossing Deaths and Spaces of Moral Alibi," Governing Immigration Through Crime A Reader, Julie A. Dowling and Jonathan Xavier Inda (eds.) Stanford University Press, 2013; "Private Detention and the Immigration Industrial Complex," International Political Sociology, December 2013, Issue 7.4, pp. 426-443; The Law Into Their Own Hands- Immigration and The Politics of Exceptionalism, University of Arizona Press, 2009; "States of Exception on the Mexico-U.S. Border: Security, 'Decisions,' and Civilian Border Patrols," International Political Sociology, Vol. 1, 2007. Roxanne is currently one of the editors for the journal International Political Sociology. Her short stories and poems have appeared in Ocotillo Review, Forge, 170 Review, Soundings Review, Four Chambers Literary Magazine, Lascaux Review, Lunaris Review, Journal of Microliterature, NewVerseNews, Saranac Review, Gateway Review and Reunion-The Dallas Review.

\section{Contact: Roxanne.doty@asu.edu}

https://journals.uvic.ca/index.php/bigreview https://biglobalization.org/ 
Borders in Globalization Review | Volume 1 | Issue 1 | Fall 2019

Doty, "Hours of the Desert"

\section{Hours of the Desert}

[Dedicated to the nearly 7000 migrants who have died crossing the U.S.-Mexico border over the past 16 years]

Published in International Times, 7/25/18

When the desert. When far from cities, but close. When Ironwood Forest and Organ Pipe and Devil's Highway. When a trail becomes a plea. Because the distance is long. When as close to god as you'll ever get. When still an illusion.

When layover spots. Because dreams. When abandoned backpacks and love letters, books of poetry, books of prayer, empty water bottles. When shade is a black plastic bag over creosote and cactus. When the sun. When days are fire, when snakes take cover.

When a bracelet on the ground. When someone wore it. Because flesh and blood. Because someone wrote the love letters, held the books of poetry and prayer. Because a heartbeat.

When still the heat. When nothing but the heat.

When the future lies beyond mountains. When it disappears. When a mirage of water. When a man with no features. When he hides in a uniform. Behind a weapon. Inside the law. When on your knees.

When grace. When compassion. When kindness. When humanity. When lost.

When you walk again. When the dream and the prayer and grace and the snake and the man cross the same desert all unaware of each other. When over and over again.

When clusters of black dots mark places of death. Because the bones. When white crosses. When no identificado. When bodies don't get counted. When they do. When counting doesn't matter. When justice is a moment. Of madness. When it dies. 